\title{
Piecing Together a Genealogical Puzzle
}

Intersectionality and American Pragmatism

Patricia Hill Collins

\section{(2) OpenEdition}

Electronic version

URL: http://journals.openedition.org/ejpap/823

DOI: 10.4000/ejpap.823

ISSN: 2036-4091

\section{Publisher}

Associazione Pragma

Electronic reference

Patricia Hill Collins, « Piecing Together a Genealogical Puzzle », European Journal of Pragmatism and American Philosophy [Online], III-2 | 2011, Online since 29 December 2011, connection on 20 April 2019. URL : http://journals.openedition.org/ejpap/823 ; DOI : 10.4000/ejpap.823

This text was automatically generated on 20 April 2019.

\section{c) () $९$}

Author retains copyright and grants the European Journal of Pragmatism and American Philosophy right of first publication with the work simultaneously licensed under a Creative Commons AttributionNonCommercial-NoDerivatives 4.0 International License. 


\title{
Piecing Together a Genealogical Puzzle
}

\author{
Intersectionality and American Pragmatism
}

Patricia Hill Collins

1 By the early-twenty-first-century, intersectionality and American pragmatism became increasingly visible discourses within U.S. academic institutions. On the surface, intersectionality and American pragmatism appear to be very different entities. Intersectionality is the newcomer on the block, an interdisciplinary discourse that, despite being only a few decades old reaches across a range of fields. ${ }^{1}$ Prevailing narratives identify critical race theorist Kimberlé Crenshaw's use of the term intersectionality in 1989 and 1991 to mark the emergence of intersectionality as a named discourse within the academy. In its over two decades as a named discourse, the ideas of intersectionality have not yet crystallized into a standard canon defined by its founding figures. Rather, intersectional scholarship and/or practice seemingly pivot on a loose set of shared ideas, namely, (1) how race, class, gender and sexuality constitute intersecting systems of power; (2) how specific social inequalities reflect these power relations from one setting to the next; (3) how identities of race, gender, are socially constructed within multiple systems of power; and (4) how social problems and their remedies are similarly constructed within intersecting systems of power. In contrast, American pragmatism has a much longer history and a broader set of practitioners. American pragmatism is typically understood as a late-nineteenth, early twentieth century philosophical tradition that is associated with the ideas of several prominent intellectuals, most notably, Charles Peirce, William James, John Dewey and George Herbert Mead. Canon-formation for American pragmatism is thus anchored in ideas of key founding figures, primarily founding fathers, rather than intersectionality's more fluid collective set of ideas that are shared by a group. The ideas of American pragmatism constitute a canon, yet its practitioners neither agree on its membership nor its main ideas.

2 These differences of longevity, practitioners, and canonical status distinguish intersectionality and American pragmatism, yet emphasizing differences may overlook 
deeper connections that might benefit both fields of study. The emergence of intersectionality and the reemergence of American pragmatism at this particular time within the academy does raise some provocative issues. In what ways, if any, might the emergence of intersectionality and American pragmatism be interrelated phenomena? Moreover, what relationship, if any, exists among the objectives, thematic content and epistemological approaches of intersectionality and American pragmatism?

Because these are very large questions, this paper focuses on one exploratory question: how might intersectionality and American pragmatism as knowledge projects inform each other? To explore this question, this essay relies on three core ideas. First, I conceptualize intersectionality and American pragmatism as knowledge projects that might fruitfully be placed in dialogue. ${ }^{2}$ Because all knowledge projects remain under construction, conceptualizing intersectionality and American pragmatism as knowledge projects might affirm current areas of emphasis within each project as well as suggest provocative new avenues of investigation for each. Second, I conceptualize these knowledge projects as being defined by their structural and symbolic boundaries (Lamont \& Molnár 2002). Structural boundaries refer to the social relations that shape a knowledge project, whereas symbolic boundaries describe the content of a field, namely, the ideas that lie within its framework and those that are excluded. ${ }^{3}$ Third, because I conceptualize intersectionality and American pragmatism as knowledge projects, they lend themselves to a genealogical approach. ${ }^{4}$ Their relationship constitutes an unfolding genealogical puzzle, with potential and actual points of contact between these two knowledge projects refracted through this framework of structural and symbolic boundaries.

4 This paper explores its core question, namely, how might intersectionality and American pragmatism as knowledge projects inform each other, by using a genealogical method to conceptualize intersectionality and American pragmatism as knowledge projects with dynamic structural and symbolic contours. Part I of the paper introduces the main ideas of intersectionality as a knowledge project as it traveled from social movement settings into American higher education. Part II takes a similar approach to American pragmatism. Part III draws from the greatly abbreviated analysis of each knowledge project in Parts I and II to investigate the theme of their potential dialogical relationship. Placing these two knowledge projects in dialogue suggests three potential points of contact, namely, their respective approaches to experience, social inequality and action.

\section{Narratives of Intersectionality}

Although Black feminism was a significant factor in catalyzing the guiding frame of intersectionality, contemporary narratives concerning the emergence of intersectionality as a knowledge project routinely ignore its links to Black feminist politics of the 1960s and 1970s. Yet examining the works of African American feminists suggest that this form of subjugated knowledge that broke though within social movement politics provides an important angle of vision for intersectionality's genealogy. For example, Toni Cade Bambara's edited volume, The Black Woman, published in 1970 stands as a groundbreaking volume of work by African American women who were involved in political struggle that can be read as a text of intersectional analysis (Bambara 1970). Taking an implicitly intersectional stance toward African American women's emancipation, African American women from diverse political perspectives presented provocative essays concerning how 
Black women would never gain their freedom without attending to race and class and gender. Written for the general public and not an academic audience, this volume can be seen as one important albeit overlooked early work within intersectionality as a knowledge project.

6 By the 1980s, some of the main ideas honed within the context of Black women's activism became crystallized within pamphlets, poetry, essays, edited volumes, art and other creative venues. In 1982, the Combahee River Collective, a small group of African American women in Boston, issued a position paper titled "A Black Feminist Statement" that laid out a more comprehensive statement of the framework that had permeated Black feminist politics (Combahee-River-Collective 1995). This groundbreaking document argued that race-only or gender-only frameworks advanced partial and incomplete analyses of the social injustices that characterize African American women's lives, and that race, gender, social class and sexuality all shaped Black women's experiences. The Statement proposed that what had been treated as separate systems of oppression were interconnected. Because racism, class exploitation, patriarchy and homophobia collectively shaped Black women's experiences, Black women's liberation required a comprehensive response to multiple systems of oppression. June Jordan's succinct statement about freedom encapsulates the thinking of the times: "Freedom is indivisible or it is nothing at all besides sloganeering and temporary, short-sighted, and short-lived advancement for a few. Freedom is indivisible, and either we are working for freedom or you are working for the sake of your self-interests and I am working for mine" (Jordan 1992: 190). Here Jordan's discussion of freedom foreshadows important ideas within intersectional knowledge projects, namely, viewing the task of understanding complex social inequalities as inextricably linked to a social justice agenda, or, the intersections not just of ideas themselves, but of ideas and actions.

7 Given the historical derogation of women of African descent, it is tempting to grant African American women ownership over the "discovery" of a yet unnamed intersectionality. Yet it is clear that African American women were part of a broader women's movement where Chicanas and other Latinas, native women and Asian American women (who subsequently became redefined collectively as women of color) were at the forefront of raising claims about the interconnectedness of race, class, gender and sexuality in their everyday lived experience. The Combahee River Collective was not alone in proposing these ideas. In the United States, for example, Latinas were engaged in similar intellectual and political struggles to create space for their empowerment within the confines of social movement politics that, like Black politics, were shaped by a patriarchal nationalism. Latina feminism came of age during these same decades of the 1970s and 1980s, with the work of Gloria Anzaldua, especially her classic volume Borderlands/La Frontera making an important contribution in framing studies of race, class, gender and sexuality (Anzaldua 1987). Anzaldua's work in particular sets the stage for examining important contemporary themes such as border space, boundaries and relationality, that have subsequently become so prominent within contemporary intersectionality.

8 Examining how women of color approached the task of their own empowerment demonstrates varying patterns of how race/class/gender/sexuality were negotiated in the context of social movement politics. For example, African American women and Chicanas confronted the task of incorporating gender into prevailing race/class analyses of the Black and Chicano nationalist movements, as well as incorporating race and class 
into a feminist movement that advanced gender only arguments. In this context, women of color's analyses about intersections of race/class/gender/sexuality were honed in the intersections of multiple social movements, a structural location that had an important effect on the symbolic dimensions of ensuing intersectional discourse.

The transitional decade of the 1980s proved to be significant, not only for the codification of the ideas of women of color in documents they produced themselves, but also as a period where social movements moved into phases of abeyance. Yet the seeming waning of social movements constituted a shift in the structural contours of knowledge projects that saw race, class, gender and sexuality as mutually constructing systems of power (referred to hereon as race/class/gender studies) as well as the venues where the symbolic contours of race/class/gender studies could develop..$^{5}$ Women of color arguing for the interconnections of race, class, gender and sexuality continued to produce documents within social movement politics, these same women were active in social movement politics. At the same time, many of these same women entered the academy as graduate students, instructors and assistant professors. It is important to remember that had social movements not fought for the inclusion of women and people of color inside the academy, that ideas that they brought with them were unlikely to have gained acceptance. The case of African American women is instructive in this regard. Alice Walker, June Jordan, Angela Davis, Nikki Giovanni, and Barbara Smith to name a few, all were actively engaged in social movements, specifically, the Civil Rights, anti-war, Black Power, women's and/or gay liberation movements. Gaining access to academic positions enabled politically active African American women to bring ideas from Black feminist politics with them into the academy through dual streams of Black feminism and race/ class/gender studies. Major works by African American women that established the groundwork for what came to be known as intersectionality included June Jordan's Civil Wars (Jordan 1981); Audre Lorde's classic volume Sister Outsider (Lorde 1984); and Angela Davis's groundbreaking volume Women, Race and Class (Davis 1981). In works such as these, one can see how Black women's intellectual production contained an explicit analysis of the interconnectedness of race, class, gender and sexuality as systems of power that was explicitly tied to varying social justice projects catalyzed by their involvement in social movement politics (Collins 2000). Again, this embrace of race/class/gender studies was not limited to African American women.

10 By this expansion into the academy, the more fluid structural and symbolic boundaries of race/class/gender studies as a knowledge project that was honed within social movements found itself fighting for space and legitimacy within prevailing academic politics. Specifically, as academic incorporation unfolded, the strategies and arguments associated with race/class/gender studies shifted. The seemingly undisciplined yet creative politics of race/class/gender studies associated with social movement politics became recast as a more disciplined, recognizable and increasingly legitimated field of inquiry.

11 The term intersectionality emerged in this border space between social movement and academic politics as a term that seemed to best capture the fluidity of intersectionality as a knowledge project. Ironically, narratives of the emergence of intersectionality rarely include this period of social movement politics, and instead confine themselves to locating a point of origin when academics first noticed, named and legitimized this emerging field of study. It's as if the ideas associated with race/class/gender studies did not exist until they were recognized by institutional actors, primarily by giving the 
emerging field a legitimate and easily transportable name. Stock stories of the emergence of intersectionality routinely claim that Kimberlé Crenshaw "coined" the term intersectionality in her Stanford Law Review article "Mapping the Margins: Intersectionality, Identity Politics, and Violence against Women of Color" (K. W. Crenshaw 1991). Interestingly, Crenshaw's earlier 1989 article also provides an important window into her conception of intersectionality, yet is not as widely cited as the 1991 article (K. Crenshaw 1989). Ironically, despite the fact that Crenshaw's article is typically invoked as a point of origin for a given author's own rendition of intersectionality, Crenshaw's ideas are less often analyzed on their own terms.

Crenshaw's 1989 and 1991 articles mark a juncture when the ideas of social movement politics became named and subsequently incorporated into the academy. When read together, both articles provide a provocative angle of vision on intersectionality as socalled travelling theory, specifically the ideas that became increasingly associated with intersectionality and those shrank in importance (Knapp 2005). Because Crenshaw's 1991 article is most often cited as the point of origin for intersectionality, here I'll briefly discuss its main points.

13 A close reading of Kimberlé Crenshaw's 1991 article does two things: (1) it identifies several main ideas of intersectionality that reappear within subsequent intersectional knowledge projects; and (2) it provides a clearer view of the interrelationship of structural and symbolic boundaries in the development of intersectionality as a knowledge project, especially what persisted, what became muted, and what disappeared. Stated differently, although routinely not read in this fashion, Crenshaw's article provides a glimpse of the structural and symbolic boundaries of intersectionality as a knowledge project at a point in time when a significant genealogical shift occurred away from social movement politics and toward academic incorporation.

Several features of Crenshaw's 1991 article foreshadow subsequent focal points within intersectionality (for an expansive discussion of these ideas, see (Collins \& Chepp, forthcoming). First, Crenshaw focuses on the experiences of women of color, a devalued group not just from the perspective of the academy, but also from society overall. Crenshaw argues that the experiences of women of color are important in and of themselves, but become especially significant in understanding and remedying important social issues. In a move that builds on her earlier article, Crenshaw places herself within her narrative where she self-identifies as a "Black Feminist." Via this move, Crenshaw signals a particular epistemological stance for the scholar in the social construction of knowledge. Experience and embodied knowledge are valorized, as is the theme of responsibility that accompanies such knowledge. In this piece, Crenshaw is working within the tenets of standpoint epistemology, acknowledging that experience broadly defined matters, not simply in incorporating the experiences of the excluded, but also in seeing women of color as differentially placed knowers and knowledge-creators. Distinctive angles of vision and challenges accompany differential social locations, a theme developed via Crenshaw's attention to the different experiences that women of color have with domestic violence. All discourses come from a particular standpoint, yet those of women of color are often obscured.

Second, Crenshaw argues that the needs of women of color cannot be met by monocategorical thinking. Crenshaw's innovation here lies in building her argument from the ground up from the experiences of women of color and then showing how multiple systems of power affect their lives not in a prioritized fashion, but instead, in a 
synergistic fashion. Mutually constructing systems of power produce distinctive social locations for individuals and groups within them, in this case, the disempowered identities that women of color carried that positioned them within complex social inequalities differently than white men or white women.

Third, Crenshaw's article contains an emphasis on relationality. By introducing the term "intersectionality," Crenshaw implicitly questions the nature of the relations among the entities that are intersecting. Crenshaw draws from the ideas of women of color developed in actual social movements who came to see that this issue of relationships was crucial - it was not enough to have a common enemy, rather, they had to figure out patterns of interconnectedness. Her argument carries this nuance in that Crenshaw includes several groups under the umbrella category "women of color," with attention to the specificity and universalities of their experiences with domestic violence. This attentiveness to relationality and its significance for coalitional politics finds an important framework in this piece. The theme of relationality permeated social movements as they had to figure out how various individuals and social movements might work together.

17 Fourth, Crenshaw's article expresses a social justice ethos that assumes that more comprehensive analyses of social problems will yield more effective social actions in response. Why write this article on women of color and violence at all, if not to provide some insight for social justice initiatives? Echoing Jordan's call that freedom is indivisible, achieving social justice for victims of domestic violence requires understanding race, class, gender and sexuality as mutually constructing systems of power. Ironically, the analysis of intersecting systems of power is secondary to the primary reason of social betterment, in this case, social betterment for women of color and for everyone else by implication. Importantly, Crenshaw is a legal scholar, and this disciplinary location might have fostered a greater attentiveness to social justice as an important dimension of intersectionality's symbolic dimensions during the era of social movement politics.

Crenshaw's article provides a useful snapshot of an important moment of transition of contemporary canon formation when intersectionality as an ostensibly novel construct travelled into the academy and was changed by its new social location. ${ }^{6}$ The academic context has a set of norms that are used to legitimate intellectual production, namely, that scholarship be objective, e.g., apolitical, decontextualized and abstract. Interestingly, Crenshaw's piece was differently objective in that it did not claim these three categories yet presented a tightly argued linear argument supported by considerable empirical evidence. Ironically, as the structural contours of social movement politics of the $1960 \mathrm{~s}$ and 1970s receded into the past, intersectionality's incorporation into the academy in the 1990 s and 2000s seemingly uncoupled this knowledge project from politics. Intersectionality as a knowledge project shifted from bottom-up knowledge projects reflected in Crenshaw's ability to draw from grassroots politics, to top-down knowledge projects whose structural contours were increasingly shaped by the normative practices of the academy, and whose symbolic contours reflected the objectives, thematic content and epistemological approaches of existing fields of study.

19 Since 1991, intersectionality as a knowledge project has expanded in the academy, gaining acceptance in many fields of study. Specifically, Women's Studies constitutes as one important interdisciplinary field that took intersectionality seriously and where scholarship most closely embraces the kind of robust social analysis evident in Crenshaw's article (see, e.g., Racialized Boundaries: Race, Nation, Gender, Colour and Class and 
the Anti-Racist Struggle, by Floya Anthias and Nira Yuval-Davis or Methodology of the Oppressed by Chela Sandoval (Anthias \& Yval-Davis 1992; Sandoval 2000). As an interdisciplinary field that drew practitioners from a wide range of disciplinary backgrounds, Women's Studies was at the forefront of curriculum transformation projects. Over time, other interdisciplinary fields of study drew upon intersectionality, most notably, cultural studies. Academic disciplines also demonstrated uneven patterns of incorporation of intersectionality. Intersectionality also found fertile ground in fields such as literature and history that valued narrative traditions and experiential knowledge. In contrast, social sciences that relied on quantitative scientific paradigms using large scale data sets came later to intersectionality. For example, political scientists expressed increased interest in intersectionality in the 2000s, bringing an important angle of vision to the field (Hancock 2007). Border disciplines between the humanities and the "hard" social sciences fell somewhere in between. Sociology, for example, was wellpositioned to develop intersectional analyses in that (1) race and class were long established subfields; (2) the field had long incorporated both humanistic and scientific paradigms; and (3) the field was characterized by diversity of practitioners, some of whom like Bonnie Thornton Dill, and Evelyn Glenn were cognizant of the significance of social movement politics to the inception of the field (Collins 2007).

Despite the significance of these and other works for scholars and researchers, the real work of establishing a field lies in building a base of undergraduate and graduate students, thus ensuring that the next generation of practitioners will emerge. In this regard, edited volumes become especially important because they "bundle" articles in ways that provide a roadmap for a field of study. Edited volumes thus shape the parameters of the field, for example, Andersen and Collins' Race, Class and Gender: An Anthology, now in its eighth edition (Andersen \& Collins 2011). As a parallel development, edited volumes that draw upon variations of the term intersectionality and that incorporate selected key articles that helped shaped this field of inquiry have begun to appear. For example, Berger and Guidroz's The Intersectional Approach: Transforming the Academy through Race, Class \& Gender seems reminiscent of curriculum transformation projects whereby women aimed to change institutional structures that produce knowledge (Berger \& Guidroz 2009). In contrast, Dill and Zambrana's Emerging Intersections: Race, Class, and Gender in Theory, Policy, and Practice sample of social science research where intersectional frameworks are apparent provides a framework for thinking through intersectional research (Dill \& Zambrana 2009). Emerging within gender studies in a German context, Lutz et al's Framing Intersectionality: Debates on a Multi-Faceted Concept in Gender Studies volume illustrates how a different national context shifts patterns of emphasis, especially concerning the theme of masculinity (Lutz, Vivar \& Supik 2011).

21 Interestingly, the volume by Lutz et al foreshadows some challenges to the prevailing narrative on intersectionality as well as challenges to the substance of the field itself. Not only can the prevailing narrative of intersectionality be unsettled by moving beyond assumptions of its American origins, the historical frame for intersectionality as a knowledge project may also be too narrow. The preceding analysis of Crenshaw's 1991 article aimed to challenge both the growing acceptance of this point of origin within intersectionality's genealogy and to suggest that starting the analysis of intersectionality earlier in social movement politics, specifically in late-twentieth-century social movement politics, might yield a more robust analysis of intersectionality. Yet choosing 
varying points of origin most likely will yield different genealogies of this field, especially reviewing earlier knowledge projects that may not have used the term intersectionality, but that may have expressed a similar ethos.

Examining the works of Ida Wells-Barnett, Anna Julia Cooper and turn-of-the-twentieth century African American women thinkers may be useful in determining another point of origin for a genealogy of intersectionality. Cooper and Wells-Barnett both advanced intersectional arguments against the dominant discourse of their times. Anna Julia Cooper's belief that "when and where I enter, then shall all enter with me," a major theme of her classic volume A Voice from the South, argues that no one can be free unless Black women gain their freedom (Cooper 1892). From Cooper's perspective as a highly educated African American woman living in the Jim Crow South, freedom required more complex arguments and accompanying politics than race-only or class-only endeavors. She inserted gender into the race/class thinking of Black social and political thought, taking a position that predates Crenshaw by close to a century concerning the intersecting nature of oppressions that affected African American women. In this regard, her analysis resembles June Jordan's construct of indivisible freedom, or the Combahee River Collective's identity politics that made Black women central and not marginal to political theory and action. Wells-Barnett pushed an intersectional analysis even further and created a scandal by writing about the centrality of race, gender and sexuality to the prevailing practice of lynching (Collins 2002). The work of Cooper, Wells-Barnett and others foreshadowed analyses of African American women's and men's oppression as situated at race, class, gender and sexuality as intersecting systems of power. At the same time, Wells-Barnett, Cooper and similar African American women thinkers routinely struggled with both Black men and white women who often used mono-categorical thinking to refute the racism, sexism and class exploitation justified by dominant discourse.

The major ideas of contemporary Black feminism that are subsequently recast as race/ class/gender studies then submerged within an academic discourse on intersectionality permeate the work of early twentieth-century African American feminists. For example, themes such as the significance of the experiences of Black women and points of view that those embodied experiences might engender, the significance of intersectional analyses of mutually constructing systems of power in Black women's lives, the relationality of complex worldviews such as those of Black and white women, or Black women and men, and of social justice as central to their political program, summarized in their slogan "lifting as we climb," all appear as themes of visionary pragmatism in the works of these early Black feminists. Yet why might these ideas have appeared when they did and taken the form that they did among this population?

Here it is important to point out that intersectionality as a knowledge project may seem new, but that intersectional analyses need not be expressions of the types of social justice agendas that have permeated the work of African American women thinkers. Anna Julia Cooper and Ida Wells-Barnett, as well as their better-known contemporaries Charles Peirce and William James, all were reacting to a broader intellectual and political context valorized science in defense of social inequality. Despite the variability among their practitioners, Black feminism and American pragmatism both emerged as alternatives to the positivist, deterministic frameworks associated with eugenics thinking. Eugenics discourse, a biologically deterministic, legitimated scientific discourse of the period of both early modern Black feminism and American pragmatism, unabashedly expressed 
racist, sexist, and anti-immigrant sensibilities. Moreover, turn-of-the-twentieth-century eugenics discourse advanced by Frances Galton and others offered explicitly intersectional analyses of complex social inequalities that helped construct and defend social injustice (Galton 1904). It stands to reason that those who bore the full brunt of eugenicist thinking about race, gender, sexuality and class, specifically, African American women, would be more likely to advance social justice arguments that were similarly intersectional than those with greater social privilege.

This move back into time that uses Black women's intellectual production as a navigational compass potentially expands contemporary understandings of the genealogy of intersectionality as well as that of American pragmatism. Incorporating latenineteenth, early twentieth century African American women's intellectual history into the emerging contemporary intersectionality canon suggests that this canon may suffer from temporal myopia. Moreover, it may be no coincidence that this same period of time when Cooper and Wells-Barnett were active is also routinely identified as the same period of time for the emergence of classical American pragmatism. Moving intersectionality back to this particular period of time highlights the significance of this same historical moment as a contested point of origin for both genealogies. In a similar fashion, intersectionality and pragmatism in the contemporary period may express similar sensibilities.

\section{Narratives of American Pragmatism}

American pragmatism has a much longer recognized history than intersectionality and, as such, lends itself to different analytical strategies. For intersectionality as a knowledge project, one can engage in a close reading of Crenshaw's work to illustrate an important turning point in the genealogy of the field. ${ }^{7}$ In contrast, the vast array of works that are recognized as legitimately belonging within American pragmatism make this an impossible approach. In light of the magnitude of this task, here I'll present a very brief overview of the recognized history of the field, a summary that provides a basic introduction to the structural contours of the field. I'll then move on to the symbolic contours by summarizing pragmatism's recognized focal points. These focal points may have received varying degrees of emphasis during different historical eras, and within different academic disciplines. Yet collectively, they do mark the symbolic boundaries of American pragmatism in that people working within the field are aware of these focal points, even if they express varying degrees of agreement or disagreement with one another concerning them (Stuhr 2000).

American pragmatism is a much broader and historically complex field of inquiry than intersectionality. This longevity means that using secondary works from and about the field as well as selected works by key figures in the field, one can identify the structural boundaries of the field, specifically its history and patterns of its ascendency, quiescence and reemergence. ${ }^{8}$ Standard accounts of American pragmatism approach it as a subfield of philosophy, whose classic or "old" version emerged in the American context over a fifty year period from late-1800s to the mid-1940s. Charles Peirce, William James, John Dewey and Charles Herbert Mead are routinely mentioned as seminal figures in the classical pragmatist canon (Gross 2007: 188; Haack 2006; Joas 1993: 4). Classical pragmatism ostensibly found "new" expressions in the contemporary period (Haack 2006). Peirce, James, Dewey and Mead are typically included in renditions of the "old" 
canon, yet the list of thinkers who appear in the "new" is far more provisional. Broadening beyond the disciplinary boundary of philosophy to incorporate other disciplines, national contexts and/or a broader time period positions a diverse array of thinkers within the pragmatist canon, among them, Ralph Waldo Emerson (West 1989: 9-41); Willaim E. B. Du Bois (Posnock 1998; West 1989: 138-49); Jürgen Habermas (Joas 1993: 125-53); Jane Addams (Seigfried 1996); and Benjamin Franklin (Campbell 1999, Pratt 2002).

Because the field is so expansive, here I review several focal points that provide some orienting constructs for the symbolic contours of American pragmatism, especially its revitalization in the contemporary period. ${ }^{9}$ First, American pragmatism emphasizes the significance of social context in the construction of knowledge. Pragmatism is always contextual in that it understands things in relational terms and not in isolation. Rather than viewing the world as consisting of essences existing in and of themselves, pragmatism approaches the social world as a series of contexts that shape the meaning and value of words, ideas, people, and institutions that are engaged in complex relationships. Pragmatism is thus concerned with understanding social phenomena that are conceptualized as dynamic and always in formation" (Dickstein 1998: 8).

Second, this emphasis on context valorizes the experiences that people have across diverse social formations. Eschewing commodified understandings of experience as essentialized entities that can be categorized and used to illustrate some overarching social theory, pragmatism places far more emphasis on experiences as negotiated by people's interactions with their social contexts. People do not passively receive or undergo experiences. Rather, experiences result from people's active engagement with their social worlds. The phrase "situated creativity" within specific social contexts captures this robust understanding of experience whereby people creatively construct their environments and whereby their environments shape human subjectivity.

30 A third dimension of American pragmatism concerns its focus on how transactional processes link experiences and social context. Rather than conceptualizing communities or democracy as finished, idealized constructs that humans try to actualize, constructs such as these are created via pragmatic action. This commitment to transactional processes within pragmatism fosters an understanding of the social self and one that is embedded in a social context. As Stuhr points out, "existence is social in a deeper, ontologically more important sense [...]: the individual is intrinsically constituted by and in his or her social relations; the self is fundamentally a social self [...] Mead develops this most fully: the self is 'essentially a social structure, and it arises in social experience'; it is thus impossible to conceive to a self arising outside of a social context" (Stuhr 2000: 7).

31 A fourth dimension of American pragmatism concerns its anti-foundationalist orientation. Pragmatism is unlikely to advance knowledge-claims that are absolute, for example, claims about the persisting reality of racism, or sexism, or the need for an ethos of social justice as a touchstone for its own project. In contrast to anti-racist projects, for example, that typically rest on the foundationalist assumption that racism is real and must be counteracted, pragmatism makes no such claims. This anti-foundationalist orientation limits pragmatism's potential as a political project in that projects with political goals typically embrace some sort of foundationalist premise that pulls their members together, for example, social justice as an ethical stance used to assess the integrity of one's project. ${ }^{10}$ 

methodology that advances specific techniques in approaching the social world, rather than making theoretical claims about the social world. Pragmatism's commitment to experimentalism stems from the goal of retaining its objectivity as a science, yet a science that can be used to shape the social world. As Dickstein points out: "working from a scientific model like the one later developed by Thomas Kuhn, Dewey envisioned a selfcorrecting community of enquirers who would proceed experimentally according to fallibilistic norms of 'warranted assertability,' instead of claiming to discover timeless truths that corresponded to the way the world actually is" (Dickstein 1998: 6). Thus, pragmatism can be seen as a malleable set of tools that can be used for a variety of purposes. principles, but for now, I want to examine how these points articulate with the contemporary period of revitalization that pragmatism shares with intersectionality. The revitalization of contemporary discourse on pragmatism operates in three interrelated sites, namely, efforts to (1) flesh out omissions or holes in the discourse, primarily by including thinkers and works that have been excluded; (2) revise the narrative to correct for existing bias and/or explicate existing themes; and (3) replace the standard narrative with one that more accurately explains the field in light of contemporary realities. The tension linking sites two and three, revising as compared to replacing the prevailing narrative, resembles the process moving from reform to transformation of the discourse. In a Kuhnian sense, a paradigm shift occurs when the old narratives of the structural and symbolic boundaries of American pragmatism no longer work, requiring something new (Kuhn 1970). Here I present a preliminary discussion of this shift from reform to transformation within pragmatism, searching for themes that may have the greatest resonance with intersectionality. ${ }^{11}$

One form of contemporary revitalization lies in efforts to revise or reform prevailing narratives of American pragmatism so that they more accurately reflect the field. Efforts at revising the canon often begin with trying to reclaim neglected or overlooked figures such as C. Wright Mills. For example, C. Wright Mills is an important pragmatist thinker who wrote his doctoral dissertation on pragmatism and who popularized the ideas of American pragmatism through his public sociology. Mills' groundbreaking volume, The Sociological Imagination, to this day remains one of the most widely read works in sociology (Mills 2000). Despite the fact that The Sociological Imagination encompasses many of the orientations of pragmatism discussed above, and that Mills' ideas had an important effect on actual social conditions, Mills is rarely included in anthologies on pragmatism. Including Mills within pragmatism raises the question of how the canon might be different had Mills's pragmatism been included. Despite the fact that Mills constitutes an important figure that stands at the crossroads of pragmatism, phenomenology and American sociology (Gross 2007), he has had few advocates within philosophy, the discipline with the strongest claim on pragmatism.

Within philosophy, the academic discipline that manages the structural and symbolic boundaries of American pragmatism, revitalization has taken the form of reclaiming neglected or overlooked figures with closer ties to philosophy than Mills. In part, this revitaliztion has reflected late-twentieth century societal trends. Just as race, gender, sexuality and other categories of analysis have become visible within the academy as well as broader society, so too have these same categories been part of efforts to revise the 
pragmatist canon. Take gender for example. Charlene Seigfried's chapter "Reclaiming a Heritage: Women Pragmatists" in Pragmatism and Feminism examines the work of women philosophers who drew upon pragmatist ideas (Seigfried 1996: 40-66). Jane Addams constitutes an important pragmatist thinker whose work has been relegated to the applied area of social work. Yet in part due to her close association with John Dewey and as a writer in her own regard, see, e.g., (Addams 2002), incorporating Addams into the pragmatist canon within philosophy by definition challenges the boundaries of what counts as pragmatism.

Much of this work on women philosophers and on feminism and pragmatism aims to reform the pragmatist canon to take gender into account. Several works stand out in this endeavor, among them, Charlene Seigfried's "Shared Communities of Interest: Feminism and Pragmatism" (Seigfried 1993, 1996); and Shannon Sullivan's analysis of the intersections of pragmatist and continental feminisms (Sullivan 2002). These efforts to examine the relationship between gendered analyses, which may or may not be feminist, and pragmatism provide a space for new avenues of investigation. For example, Shannon Sullivan revisits John Dewey's pragmatism with an eye toward reconfiguring gender (Sullivan 2000). Similarly, Mark Wood examines the implications that more closely aligning feminist standpoint epistemology with pragmatism might have for understandings of democracy (Wood, forthcoming).

Scholars of race and ethnicity have engaged in a similar process of reclaiming intellectuals for the pragmatist tradition, with an eye toward reforming it. William E. B. $\mathrm{Du}$ Bois seems the obvious choice here, primarily because Du Bois has recognition across so many fields. Thus, part of canon-revision has centered on investigating Du Bois's relationship to American pragmatism, for example, Cornel West's analysis of Du Bois as a "Jamesian Organic Intellectual" (West 1989: 138-49), or Ross Posnock's analysis of Du Bois's pragmatism and its lineage (Posnock 1998).

The focus on Du Bois is important, yet growing interest in the works of Alain Locke, an equally if not more significant figure for philosophy, illustrates the importance of incorporating neglected figures with an eye toward reforming the pragmatist canon (Fraser 1998, Harris 1999). As a philosopher who received his training at Harvard University under William James, Locke was centrally located in relation to classical American pragmatism. Both Fraser and Harris point to Locke's work (see, especially Race Contacts and Interracial Relations (Locke 1992), as expressing a "critical pragmatisms" that not only advanced understandings of race that foreshadow the contemporary period, but that also had significant implications for pragmatism's orientation to power and domination. As Fraser contends:

Many commentators have noted the overly integrative and idealist character of the social thought of the classical pragmatists. Their many important insights notwithstanding, John Dewey, George Herbert Mead, Jane Addams, and W. I. Thomas are widely seen as having failed to give adequate weight to the "hard facts' of power and domination in social life. Assuming the inevitable unfolding of an increasingly integrated world civilization, and emphasizing culture at the expense of political economy, they tended at times to posit imaginary, holistic 'solutions' to difficult, sometimes irreconcilable social conflicts. Yet Locke's 1916 lectures provide a glimpse of another pragmatism. Because he was theorizing about 'race' and racism, he linked cultural issues directly to the problem of inequality; and he stressed the centrality of power to the regulation of group differences in the United States. Thus, in contrast to the mainstream pragmatists of the World War I 
period, Locke pioneered an approach to social theory that took domination seriously. (Fraser 1998: 158-9)

the recognition of the implicit limitations of reform. The process of reclaiming ostensibly lost figures such as Locke and using this reclamation to engage in a re-reading or revision of the pragmatist canon over time, both reformist projects, hits a tipping point where the stock story of pragmatism cannot be simply fleshed out or revised. Contemporary revitalization of American pragmatism may require replacing the legitimated figures and currently agreed upon dimensions of pragmatist thought with narratives more compelling analyses for what now falls under the umbrella of American pragmatism. How would the genealogy of American pragmatism be altered by starting with a different set of thinkers, for example, with Anna Julia Cooper, Ida Wells-Barnett, or William E. B. Du Bois; or with the assumption that major pragmatist thinkers, like Mills, are often found outside the discipline of philosophy? How might our understanding of classical pragmatism be altered by placing Alain Locke in the pantheon of pragmatism's founding fathers? How would the works of Peirce, James and Dewey be included into a canon that initially excluded them? What alternative genealogies of American pragmatism exist? How would we write them?

41 Scott Pratt's volume, Native Pragmatism: Rethinking the Roots of American Philosophy, identifies a novel point of origin for American pragmatism, one that enables him to build a genealogy on the interactions among native peoples and major figures of American philosophy (Pratt 2002). Scott explores how pragmatism was not simply a method or set of tools, but rather how its contours reflected the response by its practitioners to the challenges they faced. Focusing on the "Americaness" of American pragmatism, Scott argues that one of the major themes of American national identity has been the ways in which heterogeneous populations, especiallly those of race and ethnicity, have interacted to shape all dimensions of America. Scott's radical genealogy suggests that pragmatism is "not only a critical perspective but one that tries to respond to the problems faced by those who find themselves in a place where racially different peoples meet and seek to coexist" (Pratt 2002: xii). It stands to reason that this major theme of American life would lie at the core of American pragmatism as a distinctly American philosophy, no matter how diligently later versions aim to decontextualize its particular roots. Scott's volume carefully develops three main premises: (1) the central commitments that characterize the classical pragmatism of Charles S. Peirce, William James and John Dewey are apparent much earlier in Native American thought; (2) cases exist throughout the seventeenth, eighteenth and into the nineteenth centuries that suggest Native American thought influenced European American thinkers; and (3) this more robust social, intellectual and political context out of which classical pragmatism emerged suggests that pragmatism was not simply a further development of modern European thought faced with the conditions of a "wilderness" (Pratt 2002: xii). Thus, recontextualizing pragmatism's emphasis on transactions within struggles to build communities among people with very different backgrounds on the level of local communities through the nation-building activities of America itself provides a deeper reading of American pragmatism. 

American pragmatism, yet the challenge of transforming American pragmatism goes beyond these sites of contestation. In the opening pages of her book Pragmatism and Feminism, Charlene Seigfried identifies the need to move beyond the legitimated genealogy: "I... begin by defining as pragmatism the positions developed by the members of the historically recognized movement of American pragmatism. But this is only a beginning meant to be left behind. One problem that immediately arises is that many writers defining the movement have focused almost exclusively on the pragmatic method and pragmatic theories of meaning and truth and have drawn their inferences from articles and books specifically addressed to this cluster of issues" (Seigfried 1996: 5). Themes such as how social inequalities of race, class and gender shape experiences, the centrality of power to participatory democracy, and ethical issues raised by social justice agendas might have been more centrally located within the pragmatist canon had the work by "members of the historically recognized movement of American pragmatism" not been defined as coterminous with pragmatism itself. Thus, had Alain Locke's "critical pragmatism" and Black women's "visionary pragmatism" been incorporated earlier, American pragmatism itself might have been quite different.

\section{Intersectionality and American Pragmatism in Dialogue}

Despite their differences, developing genealogies for intersectionality and American pragmatism remain under construction. Intersectionality appears to be establishing itself as a legitimated academic discourse, yet defining it too narrowly as a late-twentiethcentury academic discourse may foster premature canonical closure. In contrast, American pragmatism already has canonical status, yet finds itself revisiting its core ideas in light of challenges to its self-presentation advanced by scholars of gender and race among others. In this fluid interpretive context, placing intersectionality's and American pragmatism's orienting themes in dialogue may create space for some provocative transformative possibilities for both knowledge projects.

This paper set out to explore one core question: how might intersectionality and American pragmatism as knowledge projects inform each other? Many potential and actual points of contact between intersectionality and American pragmatism as knowledge projects exist, yet three areas seem especially germane for both projects, namely, experience, inequality and action. ${ }^{13}$

\section{Experience}

Intersectionality needs to develop a robust analysis of the importance of experience to its project and American pragmatism might provide the tools for such an analysis. Recall that Black women and Latinas used their experiences within race, class, gender and sexuality as mutually constructing systems of power to develop arguments about the centrality of intersectionality. Their experiences led them to analyze their specific social location within intersecting systems of oppression, a grounding that in turn fostered analyses of oppression itself that transcended any one individual's or any one group's experiences. Experience and speaking from the truth of one's own reality constituted an 
important dimension of Black feminism and its links to standpoint epistemology (Collins 1998: 201-68). In contrast, white men typically do not use their experiences in this way in doing intellectual work, such that the erasure of the social location of the intellectual becomes a signature feature of Western social theory, including pragmatism.

This emphasis on the validity of experience has been a major criticism of intersectionality. Within Black feminism and race/class/gender studies, the slogan the "personal is political" invoked a notion of a social self that was grounded in particular social contexts that in turn were shaped by intersecting power relations. The "personal" became "political" via a consciousness raising process of seeing how personal experiences were shaped by and shaped broader political phenomena. Yet the incorporation of intersectionality into the academy has seemingly stripped the personal of these political connotations, leaving an individual self bereft of social context. What's left seems to be an academic discourse that is increasingly characterized by an inordinate focus on how individuals construct their individual identities. Yet this emphasis on the ways that individuals perform or "do" race or gender identities, for example, elides the much broader question of why spend so much time on individual identity at all. A particular kind of personal has changed the meaning of the political in ways that highlight some aspects of the political, namely, individual choice and internal subjectivities, while erasing others, namely, structural systems of power. Intersectionality's grounding in narrative traditions raises special challenges for its practitioners who wish to refocus on the social, especially a social as organized via intersecting systems of power.

Eschewing "identity politics" not only severs identity from politics, it simultaneouly redefines experience as only valid within an interpretive framework of individual experience. More significantly, this containment of experience to individuals minimizes the significance of group-based experience. Group-based experience, and the interpretive perspective of a group of individuals with shared experiences, can only be expressed through community as a structural entity. In this sense, community is a dynamic of expression of intersecting power relations (Collins 2010). Intersectionality as a field of study initially incorporated these more robust understandings of experience, yet criticism of identity politics through this narrowing lens undercuts this dimension of intersectionality.

American pragmatism potentially becomes quite useful here, for it provides an alternative analysis of experience than that of dominant scientific discourse. When it comes to the theme of experience, intersectionality and pragmatism exhibit similarities that link their understandings of the individual in the context of community. Take, for example, Stuhr's description of pragmatism's emphasis on the centrality of experience for intersubjective understandings:

They [James \& Dewey] insist that experience is an active, ongoing affair in which experiencing subject and experienced object constitute a primal, integral, relational unity. Experience is not an interaction of separate subject and object, a point of connection between a subjective realm of the experiencer and the objective order of nature. Instead, experience is existentially inclusive, continuous, unified: it is that interaction of subject and object which constitutes subject and object - as partial features of this active, yet unanalyzed totality. Experience, then, is not an 'interaction' but a 'transaction' in which the whole constitutes its interrelated aspects. (Stuhr 2000: 4-5) 

distinctions between individual and group in mind when assessing American
pragmatism's approach to social change. Discussing American pragmatism within early twentieth century America, Cornel West casts a careful eye on pragmatism's position on reform and transformation, one with considerable implications for race, class and gender. West notes: "It promotes basic transformation at the level of the individual; for society, it supports slow gradual change. It encourages incessant transgression at the level of the individual; for society it heralds reconciliation and mediation. Last, it extols the heroic energies of willful action at the level of the individual; for society, it fosters judicious and dispassionate judgments of limits and constraints" (West 1989: 62). Despite having a robust analysis of experience that might plug some holes in intersectional discourse, as the aforementioned critics of its incorporation of race and gender as systems of inequality point out, American pragmatism has routinely overlooked some fundamental forms of experience in its own social context that shape its own functioning.

Infusing intersectionality with a pragmatist ethos regarding experience realigns contemporary configurations of intersectionality as an academic discourse with social movement approaches to race/class/gender/sexuality that advanced more robust analyses of experience, inequality, individuality and community. Rather than accepting a notion of experience as data for a more general theory, or as some sort of essentialized category that one possesses, or worse yet, identifying one group's experience as universal, normative and/or ideal, an intersectional analysis suggests that experience grounds different standpoints, providing each member of a common project a partial perspective. Individual and group-based experiences become the stuff of transactions, not something to be swept under the rug. Redefining the personal reshapes the political and redefining the political reorients the personal.

it comes to experiences, American pragmatism also has much to learn from intersectionality. Putting power and the political back into American pragmatism means seeing the individual as an important site of politics within a community that itself is conceptualized as organized around power relations. Redefining the construct of community might be useful for grappling with the "changing-same" patterns of social inequalities that characterize intersecting power relations of race, class, gender, ethnicity, sexuality, age, ability, and nation. Because the construct of community constitutes both a principle of actual social organization and an idea that people use to make sense of and shape their everyday lived realities, it may be central to the workings of intersecting power relations in heretofore unrecognized ways. Recasting the notion of community as a political construct highlights how social inequalities are organized via structural principles of community and are made comprehensible through a language of community (Collins 2010).

\section{Complex Social Inequalities}

53 A second area of convergence where a dialogue between intersectionality and American pragmatism might be useful concerns their respective treatments of complex social 
inequalities. Intersectionality stresses complex social inequalities as central to its discourse. In contrast, Alain Locke's critical pragmatism that took power and culture into account never rose to prominence within the classical pragmatist canon. As a result, American pragmatism has matured within a context where social inequalities were quite visible to its practitioners, for example, the prominence of eugenics; yet understanding and/or challenging complex social inequalities has not been explicitly part of the pragmatist canon. Pragmatism is far more developed as a canon than intersectionality, yet when it comes to the theme of complex social inequalities, or inequality at all, it has far less to say.

Standard narratives that trace the emergence and development of American pragmatism seemingly have no place for complex social inequalities. It's as if pragmatism remained unaffected by racism, sexism, heterosexism, class exploitation and nationalism shaping late-nineteenth and early-twentieth-century America. Instead, pragmatism, like Western knowledge projects in general, bracketed these systems of power out of knowledge construction except at topics of investigation. Analyses of ostensibly universalistic themes such as democracy, community, science, enlightenment, fairness were elevated over the seemingly particularistic expressions of these ideals within societies characterized by particular inequalities.

American pragmatism's early silence about social inequality is even more noteworthy given its embeddedness in turn-of-the-century social relations that were shaped by progressivism. Maintaining a split between theory and practice in its own practice (despite its theoretical content that eschewed such splits), enabled pragmatism to emerge as a discourse that could be applied to social inequalities, but one that at the same time, need say little about those inequalities as explanatory processes. Rather, the typical approach to social inequality within pragmatism has been to conceptualize social inequality as a topic or theme for empirical investigation with no inherent connection to symbolic or structural contours of American pragmatism itself.

Despite American pragmatism's seeming silences about social inequality, this discourse has important implications for understanding complex social inequalities. Catalyzed by addressing the social inequalities and attendant social problems associated with gender and race as systems of power, pragmatism's potential contributions to examining other systems of power, such as ethnicity have also been studied (Medina 2004). Moving to place the ideas of American pragmatism in dialogue with racial theory or feminist theory represents a step along this same path. Here the work of pragmatists who work directly with both traditions, for example, pragmatism and gender, or pragmatism and race, are positioned not simply to apply the ideas of pragmatism to contemporary social issues, but rather to push the boundaries of pragmatism in ways that test its validity as a critical social theory. These efforts by feminists and critical race scholars to place pragmatism in dialogue with analyses of gender and race collectively point to how the stock story of pragmatism becomes altered when these issues are considered. Yet these are monoissues, either gender or race or ethnicity that eschew yet are moving toward the intersectionality of complex social inequalities. Stated differently, the contemporary revitalization of American pragmatism with its attendant efforts to flesh out, revise and/ or replace the prevailing stock story place American pragmatism on a trajectory that points it toward intersectionality.

When it comes to the treatment of complex social inequalities within American pragmatism, two themes stand out. For one, individual figures within a broader 
pragmatist movement may have developed analyses of one form of social inequality, race or gender, or class, but American pragmatism overall did not explicitly concern itself with social inequality as part of its method. This is especially ironic, given the prevalence of eugenics as a clearly intersectional scientific discourse during American pragmatism's rise, with its clear attention to race, class, gender, sexuality and ethnicity as interconnected (see, e.g. Galton 1904). This was the interpretive context against which American pragmatism defined itself as a science, yet the theme of social inequality was as taken for granted by pragmatists as it was a major preoccupation of eugenicists.

For another, the lack of attention to social inequality as a pillar of pragmatism meant that a more sophisticated analysis of social inequality, e.g., one informed by intersectional analyses of systems of power, was not forthcoming during its moment of ascendency in the late nineteenth, early twentieth century. American pragmatism had important implications for inequality, yet as a method or tool that could be put to a variety of purposes: "for progressive thinkers it meant that the sources of social inequality, far from being a given, could be traced empirically and altered by changes in education and public policy" (Dickstein 1998: 4). In another irony, the very tenets of pragmatism concerning social context and its emphasis on transactional analyses suggests that efforts to view any discourse as a decontextualized methodology suspect. Rather, American pragmatism chose to see certain aspects of social reality as being amenable to so-called melioration and others as taken-for-granted essentials.

Thus, the treatment of social inequality within American pragmatism points to the ironies that permeate this discourse. This can be explained in part by its status as a theory of method or as a method rather than as a theory of society (one characterized by inequality). Thus, one of the more significant contributions of intersectionality may lie in its ability to develop a more robust understanding of complex social inequalities that can be used to animate existing initiatives within American pragmatism. Understanding complex social inequalities lies at the heart of intersectionality's symbolic and structural contours. Might inequality become another master category within American pragmatism? This is an area for future dialogue and development.

\section{Social Action}

Pragmatism and intersectionality have another point of contact where a dialogue might be beneficial. Both discourses emphasize social action, and their respective approaches might inform one another. Pragmatism's theory of action emphasizes human action in the social world whereby knowledge itself reflects human beings' actions. As social phenomena, identities are never finished but are always in the making via human engagement with the social world. Similarly, knowledge or "truths" are not absolute, and must be evaluated by how well they function (their pragmatic value). By viewing the social world as always in the making and malleable and placing social actors in this world as thinking beings who bring science or "intelligent thought" to the process of making the world, pragmatism creates space to valorize human creativity and agency. This robust understanding of human action as situated at the intersection of ideas and practice is vital in meeting contemporary challenges. For example, John Dewey's conception of an educated public that might act in the best interests of the group relies on individuals whose "intelligent thought" brings the best ideas to the table for participatory democracy (Dewey 1954). 
61 In discussing the significance of pragmatism for contemporary social theory, German theorist Hans Joas identifies one conundrum that lies at the heart of American pragmatism that affects both perceptions of it as well as its orientation as a theory of action: "It is my contention that American pragmatism is characterized by its understanding of human action as creative action. The understanding of creativity contained in pragmatism is specific in the sense that pragmatism focuses on the fact that creativity is always embedded in a situation, i.e., on the human being's 'situated freedom"' (Joas 1993: 4) ${ }^{14}$ Joas's description aptly describes exactly what Black women and Latinas and many others did during the social movement phase that catalyzed the emergence of intersectionality. The conundrum for American pragmatism lies in its desire to examine human creativity without unduly embedding itself in actual situations that have varying degrees of "situated freedoms." The Americanness of American pragmatism comes into play here, in that freedom has historically been refracted through power relations of race, class, gender and sexuality.

Despite pragmatism's potential, its actual approach to social action has been shaped by the broader social context in which pragmatist thinkers as social actors have been situated and which they aim to shape. As a theory of action, pragmatism's emphasis on maintaining social order with its concomitant ideas of incremental change and reformism reflects the social locations of its founding fathers and their subsequent practitioners. Hans Joas explains this connection between pragmatism's approach to action and its corresponding emphasis on social order: "Pragmatism is a philosophy of action [...] It does not, however, attack utilitarianism over the problem of action and social order, but over the problem of action and consciousness. Pragmatism developed the concept of action in order to overcome the Cartesian dualisms [...] Pragmatism's theory of social order, then, is guided by a conception of social control in the sense of collective selfregulation and problem-solving" (Joas 1993: 18). This approach to action and social order enables pragmatism to imagine that the structure of communication within communities of scientists, in other words, the "intelligent thought" required to participate in informed dialogue, should serve as the model for communities and democratic institutions.

Despite its provocative ideas about social action that might work in theory, pragmatism remains limited as a theory of social action, primarily because it underemphasizes the significance of power in shaping social action. Ignoring power relations, specifically those of class, race and gender that have been so prominent in the American setting, leaves pragmatism adrift. Without some sort of guiding principles to help people place value on ideas - for example, racism, sexism and class exploitation are socially unjust and their continuation harms democratic processes - dialogues can continue on in infinite loops of communicative understandings that lack any overarching social meaning. Action is not guided simply by rationality, by considering all the options, acting, and then folding new knowledge back into a feedback loop of recursive understanding. American pragmatism remains inherently reactive to social conditions because it does not adhere to a program of what it wants to do. Pragmatism's versatility enhances its capacity for action, yet its failure to embrace any guiding principles as central to the symbolic contours of its discourse means that it tools can used for a variety of ends. This stance makes American pragmatism not fatally flawed, but rather incomplete. As a knowledge project, intersectionality's understanding of social action, that knowing and doing remain intertwined in the context of specific political projects, frames its understanding of action. Here the visionary pragmatism as expressed by African 
American women engaged in early-twentieth-century social movements provides a model for thinking about agency, community and social change that seems directly influenced by pragmatism, but is less often recognized as such. The theme of Black women's visionary pragmatism is part of this tradition (Collins 2009: 175-83; James \& Busia 1993). Two elements of visionary pragmatism are especially significant. On the one hand, people who embrace visionary pragmatism believe in taking principled stances to guide behavior. Visionary pragmatism consists of choosing to commit to principles that can be used to guide human action. ${ }^{15}$ For example, for African American women social justice has been a core principle that has simultaneously grounded Black feminism yet provided a set of ideas to guide behavior (Collins 1998). African American women believe that racism and sexism are morally bad and these beliefs simultaneously shape behavior and are shaped by Black women's actions. On the other hand, people who embrace visionary pragmatism do not live lives organized solely by abstract principles. Instead, they make pragmatic choices in specific social contexts, thus embracing a more robust understanding of the pragmatic than simple practicality. For example, African Americans' "situated creativity" or, in the words of historian Robin D. G. Kelley, their "radical imagination" concerning Black freedom struggle has been honed through this recursive process of always testing ideas in the crucible of experience (Kelley 2002). Visionary pragmatism combines both of these elements of having a broader vision of why engage in social action in the first place, and being equipped with functional tools that enable people to advance that vision in varying social locations. Stated differently, pragmatic choices reflect the principled stances that people take in response to the constraints and opportunities associated with specific social contexts.

Black women's visionary pragmatism has long expressed this creative tension between the desirable, the possible, the probable and the practical. With each iteration of a particular vision, or of ever-changing particular ways of experiencing the world, everyday life is something that is rooted, grounded, contingent, dynamic, and holistic. It is characterized by infinite opportunities to engage in critical analysis and take action. In everyday life, principles give life meaning and actions make it meaningful. It matters which particular principles one stands for. Depending on what kind of social context you are in, you have the opportunity if not the responsibility of seeing how specific principles manifest themselves.

My concern is that this robust version of social action encapsulated by visionary pragmatism is rapidly disappearing in response to intersectionality's legitimation within the academy. Shorn of its connection to visionary pragmatism, or, as discussed earlier, to more robust understandings of individual and group-based experience and a lived understanding of complex social inequalities, intersectionality is fast becoming just another theory of truth that can be manipulated for a variety of ends. In this regard, intersectionality in the academy remains unfinished in that it claims part of the broader corpus of work that catalyzed it, yet it leaves the ethical and political dimensions of social movement politics behind as being non-scholarly and too activist. Yet what is a theory of action that cannot explain its own "action" strategies? Its own culpability in shaping the world around it?

67 As theories of action situated within complex power relations, intersectionality and American pragmatism both must attend to the kinds of experiences they sanction and censure. Moreover, as future-oriented knowledge projects, both necessarily build upon the past, yet neither need remain there. The brief genealogies of intersectionality and 
American pragmatism presented here were meant to summarize each discourse in order to unsettle it. My goal has been to provide useful for insights for paths not taken within each discourse, with an eye toward continual revision of what counts as the legitimated canon of each area. Moving forward has required looking back. The real challenge for intersectionality and American pragmatism lies in continuing this stance of internal and external interrogation, recognizing that remaining unfinished may be the essential skill needed for the future.

\section{BIBLIOGRAPHY}

ADDAMS J., (2002), Democracy and Social Ethics, Urbana, University of Illinois Press.

ANDERSEN M. L. \& P. H. collins (eds.), (2011), Race, Class and Gender: An Anthology (8th. ed.), Belmont, Wadsworth.

ANTHIAS F. \& N. YUVAL-DAVIS, (1992), Racialized Boundaries: Race, Nation, Gender, Colour and Class and the Anti-Racist Struggle, New York, Routledge.

ANZALDUA G., (1987), Borderlands/La Frontera, San Francisco, Spinsters/Aunt Lute Press.

BAmBARA T. C., (ed.), (1970), The Black Woman: An Anthology, New York, Signet.

BERGER M. \& K. GUIDROZ (eds.), (2009), The Intersectional Approach: Transforming the Academy through Race, Class \& Gender, Chapel Hill, University of North Carolina Press.

BERGER P. L. \& T. LUCKMANN, (1966), The Social Construction of Reality: A Treatise in the Sociology of Knowledge, New York, Anchor.

CAMPBELL J., (1999), Recovering Benjamin Franklin, Chicago, Open Court.

ColuINS P. H., (1998), Fighting Words: Black Women and the Search for Justice, Minneapolis, University of Minnesota Press.

Collins P. H., (2000), Black Feminist Thought: Knowledge, Consciousness, and the Politics of Empowerment (2nd ed.), New York, Routledge.

Collins P. H., (2002), “Introduction to On Lynchings," in I. B. Wells-Barnett (ed.), On Lynchings, Amherst, Humanity Books, 9-24.

Collins P. H., (2005), “An Entirely Different World: Rethinking the Sociology of Race and Ethnicity," in Calhoun C., Turner B. \& Rojek C. (eds.), Handbook of Sociology London, Sage, 208-22.

Collins P. H., (2007), "Pushing the Boundaries or Business As Usual? Race, Class, and Gender Studies and Sociological Inquiry," in Calhoun C. (ed.), Sociology in America: A History, Chicago, University of Chicago Press, 572-604.

Collins P. H., (2009), Another Kind of Public Education: Race, Schools, the Media and Democratic Possibilities, Boston, Beacon Press.

Collins P. H., (2010), “The New Politics of Community,” American Sociological Review, 75 (1), 7-30. 
Collins P. H. \& V. Chepp, (forthcoming), “Intersectionality," in Weldon L. (ed.), Oxford Handbook of Gender and Politics, New York, Oxford.

COMBAHEe-River-Collective, (1995), “A Black Feminist Statement,” in Guy-Sheftall B. (ed.), Words of Fire: An Anthology of African-American Feminist Thought, New York, The New Press, 232-40.

COOPER A. J., (1892), A Voice from the South; By a Black Woman of the South, Xenia, Ohio, Aldine.

CRENSHAW K., (1989), "Demarginalizing the Intersection of Race and Sex: A Black Feminist Critique of Anti-Discrimination Doctrine, Feminist Theory, and Anti-Racist Politics," The University of Chicago Legal Forum 139.

CRENSHAW K. W., (1991), "Mapping the Margins: Intersectionality, Identity Politics, and Violence against Women of Color," Stanford Law Review, 43 (6), 1241-99.

DAVIS A. Y., (1981), Women, Race, and Class, New York, Random House.

DE WAAL C., (2005), On Pragmatism, Belmont, Wadsworth Press.

DEWEY J., (1954), The Public and Its Problems, Athens, Ohio University Press.

DICKSTEIN M., (1998), "Introduction: Pragmatism Then and Now," in M. Dickstein (ed.), The Revival of Pragmatism: New Essays on Social Thought, Law, and Culture, Durham, Duke University Press, 1-18.

Dill B. T. \& R. ZAmBranA, (eds.) (2009), Emerging Intersections: Race, Class, and Gender in Theory, Policy, and Practice, New Brunswick, Rutgers University Press.

FouCAult M., (1980), Power/Knowledge: Selected Interviews and Other Writings, 1972-1977 (C. Gordon, Trans.), New York, Pantheon.

FRASER N., (1998), “Another Pragmatism: Alain Locke, Critical 'Race' Theory, and the Politics of Culture," in M. Dickstein (ed.), The Revival of Pragmatism: New Essays on Social Thought, Law, and Culture, Durham, Duke University Press, 157-75.

GALton F., (1904), “Eugenics: Its Definition, Scope, and Aims,” American Journal of Sociology, 10 (1), $1-6$.

GLAUDE E. S., (2007), In a Shade of Blue: Pragmatism and the Politics of Black America, Chicago, University of Chicago Press.

Gross N., (2007), "Pragmatism, Phenomenology, and Twentieth Century American Sociology," in Calhoun C. (ed.), Sociology in America: A History, Chicago, University of Chicago Press, 183-224).

HAACK S., (2006), "Introduction: Pragmatism, Old and New," in Haack S. (ed.), Pragmatism: Old and New Amherst, New York, Prometheus Books, 15-67.

HANCOCK A.-M., (2007), “When Multiplication Doesn't Equal Quick Addition: Examining Intersectionality as a Research Paradigm," Perspectives on Politics, 5 (1), 63-79.

HARRIS L., (1999), The Critical Pragmatism of Alain Locke, Lanham, Rowman \& Littlefield.

HICKMAN L. A., (2007), Pragmatism as Post-Postmodernism: Lessons from John Dewey, New York, Fordham University Press.

JAMES S. M. \& A. P. A. BUSIA (eds.), (1993), Theorizing Black Feminisms: The Visionary Pragmatism of Black Women, New York, Routledge.

JOAS H., (1993), "Pragmatism and Social Theory," Chicago, University of Chicago Press.

JORDAN J., (1981), “Civil Wars,” Boston Beacon Press. 
JORDAN J., (1992), “Technical Difficulties: African-American Notes on the State of the Union,” New York, Pantheon Books.

KELLEY R. D. G., (2002), “Freedom Dreams: The Black Radical Imagination,” Boston, Beacon.

KNAPP G.-A., (2005), "Race, Class, Gender: Reclaiming Baggage in Fast Travelling Theories," European Journal of Women's Studies, 12 (3), 249-65.

KUHN T. S., (1970), “The Structure of Scientific Revolutions," Chicago, University of Chicago Press. LAWSON B. E. \& D. F. Косн (eds.), (2004), Pragmatism and the Problem of Race, Bloomington, Indiana University Press.

LOCKE A. L., (1992), Race Contacts and Interracial Relations, Washington, Howard University Press. LORDE, A., (1984), Sister Outsider: Essays and Speeches, Freedom, Calif., Crossing Press.

LUTZ H., VIVAR M. T. H. \& L. SUPIK (eds.), (2011), Framing Intersectionality: Debates on a Multi-Faceted Concept in Gender Studies, Surrey, England, Ashgate.

MEDINA J., (2004), "Pragmatism and Ethnicity: Critique, Reconstruction, and the New Hispanic," Metaphilosophy, 35 (1/2), 115-46.

MENAND L., (1997), “An Introduction to Pragmatism," in L. Menand (ed.), Pragmatism: A Reader, New York, Vintage, xi-xxxiv.

MENAND L., (2001), The Metaphysical Club: A Story of Ideas in America, New York, Farrar, Straus and Giroux.

MILLS C. W., (2000), The Sociological Imagination, New York, Oxford.

OMI M. \& H. WINANT, (1994), Racial Formation in the United States: From the 1960s to the 1990s, New York, Routledge.

POSNOCK R., (1998), "Going Astray, Going Forward: Du Boisian Pragmatism and Its Lineage," in Dickstein M. (ed.), The Revival of Pragmatism: New Essays on Social Thought, Law, and Culture, Durham, Duke University Press, 176-89.

PRATT S. L., (2002), Native Pragmatism: Rethinking the Roots of American Philosophy, Bloomington, Indiana University Press.

RORTY R., (1999), Philosophy and Social Hope, New York, Penguin.

SANDoval C., (2000), Methodology of the Oppressed, Minneapolis, University of Minnesota Press.

SEIGFRIED C. H., (1993), "Shared Communities of Interest: Feminism and Pragmatism," Hypatia, $8(2), 1-14$

SEIGFRIED C. H., (1996), Pragmatism and Feminism: Reweaving the Social Fabric, Chicago, University of Chicago.

STUHR J. J., (2000), “Introduction: Classical American Philosophy,” in Stuhr J. J. (ed.), Pragmatism and Classical American Philosophy: Essential Readings and Interpetive Essays, New York, Oxford University Press, 2nd ed., 1-9.

Sullivan S., (2000), "Reconfiguring Gender with John Dewey: Habit, Bodies, and Cultural Change," Hypatia, 15 (1), 23-42.

SUlLIVAN S., (2002), "Intersections Between Pragmatist and Continental Feminism," in Zalta E. N. (ed.), The Stanford Encyclopedia of Philosophy, Stanford, Stanford University, Metaphysics Research Lab. 
WEST C., (1989), The American Evasion of Philosophy: A Genealogy of Pragmatism, Madison, University of Wisconsin Press.

wooD M. D., (forthcoming), Deepening Democracy in Rebuilding the Civil Sphere: Interweaving

Pragmatism And Feminist Standpoint Theory.

\section{NOTES}

1. Currently housed within a broad and interdisciplinary body of scholarship, the idea of intersectionality weaves across multiple disciplines, garnering increasing acceptance within social science fields as diverse as sociology, psychology, economics, and political science. Fields that have been oriented to public practice have shown a special receptivity to intersectionality. For example, intersectionality's close affinity with legal scholarship, specifically Critical Race Theory and LatCrit theory, highlights the ways in which the analytical strategies of intersectionality have been cultivated in an intellectual context explicitly devoted to social action and change. Similarly, the field of public policy finds utility in intersectional analyses for understanding how intersectional social locations impact life choices. Intersectionality has also made significant contributions to the field of public health, where social determinants of health disparities are increasingly approached from intersectional perspectives. For a discussion and relevant citations for these literatures, see (Collins \& Chepp, forthcoming).

2. In this essay, I conceptualize intersectionality and American pragmatism as knowledge projects. A sociology of knowledge framework suggests that knowledge is socially constructed and transmitted, legitimated and reproduced by social mechanisms deeply intertwined with (intersecting) social systems of power (Berger \& Luckmann 1966). My understanding of the term "project" parallels Michal Omi and Howard Winant's definition of racial formations and racial projects. They note: "We define racial formation as the sociohistorical process by which racial categories are created, inhabited, transformed, and destroyed [...] we argue that racial formation is a process of historically situated projects in which human bodies and social structures are represented and organized" (Omi \& Winant 1994: 55-6). Stuhr's description of American pragmatism parallels my approach to both fields: "it may be defined by its exponents' common attitudes, purposes, philosophical problems, procedures, terminology, and beliefs. It is in virtue of such a shared complex of features that we identify, understand, and differentiate philosophical developments, movements, and 'schools of thought.' Such a unity of character, we must recognize, is not a single and simple essence, some necessary and sufficient feature of classical American philosophy, some property present always and only in classical American philosophy. Instead, it is an identifiable configuration, a characteristic shape, a resemblance, an overlapping and interweaving of features (present to differing degrees in the writings of the individual philosophers) that, as a relational whole, pervades and constitutes this philosophy and these philosophers" (Stuhr 2000: 2-3). In this essay, I use the terms narrative, discourse and canon interchangeably, although there are nuances. I approach intersectionality and American pragmatism as broader knowledge projects that may have additional aspects beyond their formal content of their ideas.

3. Approaching these fields of inquiry as knowledge projects enables me to analyze the changing configurations of symbolic and structural boundaries that characterize intersectionality and American pragmatism. Structural and symbolic boundaries are intimately linked in that structural power arrangements legitimate ideas that can work to uphold and/or challenge the social structural organization of a field of inquiry. Using an internalist framework to analyze a canon means looking solely at the ideas themselves, namely the symbolic contours untethered from structural power relations. Yet ignoring the structural contours of discourse, knowledge 
project or canon can foster a superficial understanding of a discourse's symbolic contours. For both American pragmatism and intersectionality, it mattered greatly who advanced knowledge claims, the social context in which they advanced them, and the power relations that housed these structural and symbolic phenomena.

4. Here I draw upon Foucault's discourse analysis, in particular, his notions of discourse as characterized by periods of ascendency and decline. See "Two Lectures" (Foucault 1980). Whereas I do not see pragmatism exclusively as a middle class, American project, this essay is informed by Cornel West's description of genealogy in his book length monograph on American pragmatism. West notes: "My basic aim in this book is to chart the emergence, development, decline, and resurgence of American pragmatism. I understand American pragmatism as a specific historical and cultural product of American civilization, a particular set of social practices that articulate certain American / desires, values, and responses and that are elaborated in institutional apparatuses principally controlled by a significant slice of the American middle class" (West 1989: 4-5).

5. Using contemporary terms to describe an entity that was emerging and that had not yet been named remains challenging. Astute readers should notice that, despite the incorporation of sexuality within the work of prominent Black feminists, sexuality did not emerge on equal footing or necessarily intersecting with race, class and gender during this period of academic incorporation.

6. Crenshaw's piece may have been so well-received, in part, because it demonstrated the ability to fuse the sensibilities of social movement politics and its commitment to social justice initiatives with sophisticated theoretical perspectives, in particular, the growing significance of postmodern and poststructuralist analyses within the late-twentieth-century American academy. Crenshaw thus spoke to two audiences within academia, namely, those with a social movement background who understood the social justice ethos of the piece, and a readership that recognized the theoretical framework that Crenshaw invoked.

7. The genealogy of intersectionality presented here is narrow. Here I can only allude to other places, spaces and times where similar ideas may have been expressed within knowledge projects that we have not yet seen as part of one larger, interpretive whole.

8. A series of anthologies of the works of key figures in the field provide a generally agreed upon history of American pragmatism (late-nineteenth-century origins to contemporary expressions as a uniquely American philosophy) that is explained by the following provisional chronology: (1) the founding of the field, primarily through seminal essays activities of participants in the "Metaphysical Club"; (2) the maturing of the field through the copious works of philosopher John Dewey; (3) a period of decline during the 1940s and 1950s when Dewey's ideas went out of favor; and (4) a period of resurgence and revitalization, marked by new social movements in 1960 s and 1970s and the increased scholarly attention to the ideas themselves in the 1980s-present. According to the stock story, by the 1980s and 1990s, American pragmatism became revitalized in the academy, especially within philosophy. Two philosophers are identified as spearheading this movement. Richard Rorty catalyzed a neo-pragmatism (Rorty 1999). German philosopher Jurgen Habermas also turned to American pragmatism for its utility in shaping his theories of communicative action and democracy, a move that further gave legitimacy to the field. It also reappeared within other disciplines that had drawn upon pragmatism but had not recognized it as such. Given the period of quiescence, the revitalization of American pragmatism has been significant.

9. There appear to be just as many versions of American pragmatism as there are American pragmatists. For useful taxonomies, see De Waal 2005; Dickstein 1998; Glaude 2007; Gross 2007; Haack 2006; Joas 1993; Menand 1997; Stuhr 2000; and West 1989.

10. On the one hand, this anti-foundationalism can be seen as a critical response to the foundationalist projects advanced within Western knowledge, for example, the biologically 
determinist eugenics projects described earlier. Part of this anti-foundationalism lies in pragmatism's space for diversity and heterogeneity. As Dickstein points out, "pragmatism, like modernism, reflects the break-up of cultural and religious authority, the turn away from any simple or stable definition of truth, the shift from totalizing systems and unified narratives to a more fragmented plurality of perspectives" (Dickstein 1998: 4). Yet diversity without purpose can result in cacophony. Thus, on the other hand, the absence of foundational stances, for example, the reality of racism within anti-racist projects, or of patriarchy within feminist scholarship, or capitalist exploitation within Marxist social thought, can maroon pragmatism as a rudderless knowledge project.

11. Because American pragmatism writ large did undergo a period of quiescence, fleshing out this discourse takes the form of raising awareness of pragmatism itself, as well as its themes and practitioners. Revitalization aims to make the ideas of pragmatists available to contemporary readers. The publication of several edited volumes that aim to identify the major works of major pragmatist thinkers seems designed to flesh out the works of thinkers who already are legitimated pragmatist thinkers. Works in this tradition include Louis Menand's Pragmatism: A Reader (Menand 1997); Susan Haack's Pragmatism, Old and New (Haack 2006); and John J. Stuhr's Pragmatism and Classical American Philosophy (Stuhr 2000); Each of these anthologies has a different focus, which accounts in part, for the differing individuals who are identified as being major figures that can be included in anthologies.

Book length monographs illustrate another mechanism for aiming to map the structural and symbolic contours of American pragmatism as a knowledge project. A sampling of recent volumes illustrates the different approaches and areas of emphasis presented by thinkers who aim to synthesize the main ideas of the field and/or explore its trajectory. Louis Menand's The Metaphysical Club: A Story of Ideas in America is a work of fiction written for a general audience, yet this volume also serves as a solid introduction to the core ideas of Menand's analysis of the founders of the field. Menand's work links ideas of pragmatism to a distinctly American setting (Menand 2001).

Because prevailing narratives of pragmatism position it within philosophy as a discipline, several monographs map its trajectory within this field. For example, Cornelis De Waal's On Pragmatism (De Waal 2005) provides a solid summary of main ideas and history for philosophy students. Hans Joas's Pragmatism and Social Theory (Joas 1993) emphasizes expressions of pragmatism in the U.S. and Europe. Cornel West's volume The American Evasion of Philosophy: A Genealogy of Pragmatism (West 1989), aims to broaden the pragmatist canon to include themes and thinkers that routinely did not appear in histories. Focusing on pragmatism as a sub-field of philosophy, West aimed to show pragmatism's potential utility for a more democratic agenda. Scott L. Pratt engages in a similar project. In Native Pragmatism: Rethinking the Roots of American Philosophy (Pratt 2002) Pratt also examines the connections between pragmatism and philosophy, yet casts a much wider net than West and others by his incorporation of the encounter between native peoples and settlers as core (Pratt 2002). Still within this tradition of linking pragmatism within the confines of philosophy specifically and social theory in general, Larry A. Hickman's Pragmatism as PostPostmodernism: Lessons from John Dewey examines the provocative thesis that pragmatism may constitute the next step after post-structuralism (Hickman 2007). This is yet another expression of revival.

12. Work on race and ethnicity continues to push the envelope concerning pragmatism's relationship to the social issue of race (Lawson \& Koch 2004), as well as its utility as a framework for understanding African American political action (Glaude 2007). For an analysis of the distinctions between race and ethnicity, see Collins 2005.

13. It is beyond the scope of this paper to develop these ideas beyond a cursory summary. However, several ways in which these and other themes might be related provide a provocative anchor for piecing together a dialogical space for intersectionality and pragmatism. Such 
dialogues can be synergistic (e.g., areas of emphasis in one overlap with those of the other area such that they have influenced one another); complementary (e.g., areas of emphasis in one fit together with areas of neglect in the other); conflicting (e.g., they move in different directions regarding some entity); and/ or unrelated (e.g., there may be elements of one that are simply not relevant to the overall aspirations of the other knowledge project).

14. Joas also points out that this dimension of American pragmatism has garnered criticism: "It is precisely this emphasis on the interconnection of creativity and situation that has given rise to the repeated charge that pragmatists merely possess a theory that is a philosophy of adaptation to given circumstances. This accusation fails to perceive the antideterministic thrust of the pragmatists. In their view the actors confront problems whether they want to or not; the solution to these problems, however, is not clearly prescribed beforehand by reality, but calls for creativity and brings something objectively new into to world" (Joas 1993: 4).

15. Here I make a distinction between principles and ideology, theology or dogma. Principles are core ideas that will never be actually realized but that will always be tested in each new social formation. For example, taking action against color-conscious racism fostered the noble ethos of colorblindness. Yet the very principle of colorblindness was tested through the emergence of colorblind racism, a seeming oxymoron. Unless one can imagine a world where all vestiges of a 500-year systems of global racism are eradicated, there will always be the need to take action against racism.

\section{ABSTRACTS}

The emergence of intersectionality and the reemergence of American pragmatism within the academy in the late-twentieth century raises some provocative issues. On the surface, intersectionality and American pragmatism appear to be very different entities, yet emphasizing their differences may overlook deeper connections that might benefit both discourses. Using a genealogical method, this essay explores one core question: how might intersectionality and American pragmatism as knowledge projects inform each other? The body of the essay presents an abbreviated analysis of the structural and symbolic contours of each knowledge project so that the theme of their potential dialogical relationship can be investigated. The essay concludes by examining three areas of convergence that emerge from this preliminary dialogue, namely, themes of experience, complex social inequalities and conceptions of social action.

\section{AUTHOR}

\section{PATRICIA HILL COLLINS}

University of Mariland

collinph[at]umd.edu 